\title{
Pengaruh Variasi Suhu dan Ketebalan Irisan Kunyit pada Proses Pengeringan terhadap Sifat Fisik Tepung Kunyit
}

\section{Effect of Drying Temperature and Slice Thickness of Tumeric on Drying Process on Physical Tumeric Flour}

\author{
Ni Putu Intan Oktavia Fitriani, Ni Luh Yulianti*, Ida Bagus Putu Gunadnya \\ Program Studi Teknik Pertanian Fakultas Teknologi Pertanian Universitas Udayana, Badung, Bali, Indonesia \\ *email: yulianti@unud.ac.id
}

\begin{abstract}
Abstrak
Tujuan dari penelitian ini adalah untuk mengetahui pengaruh variasi suhu dan ketebalan irisan kunyit terhadap kualitas tepung kunyit yang dihasilkan dan untuk mengetahui perlakuan terbaik yang menghasilkan tepung kunyit dengan kualitas yang baik. Penelitian ini menggunakan rancangan acak lengkap faktorial (RAL) dengan dua faktor yaitu faktor pertama suhu pengeringan $50^{\circ} \mathrm{C}$ dan $60^{\circ} \mathrm{C}$, dan faktor yang kedua yaitu ketebalan irisan $0,5 \mathrm{~cm}, 1 \mathrm{~cm}$, dan $1,5 \mathrm{~cm}$. Parameter yang diamati yaitu kadar air, sudut curah, indeks keseragaman, kerapatan curah, rendemen butiran dan warna. Hasil penelitian menunjukkan bahwa interaksi perlakuan berpengaruh terhadap parameter kerapatan curah, indeks keseragaman, rendemen butiran, dan warna. Sedangkan perlakuan suhu pengeringan dan ketebalan irisan memberikan pengaruh yang signifikan terhadap parameter kadar air dan sudut curah. Selanjutnya berdasarkan hasil olah data dapat disimpulkan bahwa perlakuan suhu pengeringan $60^{\circ} \mathrm{C}$ dan ketebalan irisan $1 \mathrm{~cm}$ merupakan perlakuan yang terbaik dengan nilai kadar air sebesar $12,5 \%$, sudut curah $36,2^{\circ}$, indeks keseragaman mesh 40 sebesar 91,2\%, mesh 60 39,9\%, mesh 80 38,1\%, kerapatan curah 0,428kg/cm ${ }^{3}$, rendemen butiran $25,3 \%$, dan warna tepung kuning-oranye.
\end{abstract}

Kata Kunci: suhu pengeringan, ketebalan irisan, tepung kunyit, kadar air, sudut curah

\begin{abstract}
Abtract
The purpose of this study is to determine effect of variations in temperature and thickness of turmeric slices on the quality of turmeric flour produced and to determine the best treatment that produces turmeric flour with good quality. This study used a factorial completely randomized design (CRD) with two factors: the first factor was the drying temperature of $50^{\circ} \mathrm{C}$ and $60^{\circ} \mathrm{C}$, and the second factor was the thickness of the slices $0.5 \mathrm{~cm}, 1 \mathrm{~cm}$ and $1.5 \mathrm{~cm}$. The parameters observed were water content, angle of repose, uniformity index, grain yield, bulk destiny and color. The results showed that the interaction of treatment affected the parameters of bulk density, uniformity index, grain yield, and color. While the treatment of drying temperature and thickness of the slices have a significant effect on the parameters of water content and angle of repose. Furthermore, based on the results of data processing, it can be concluded that the treatment temperature of $60^{\circ} \mathrm{C}$ drying and slice thickness of $1 \mathrm{~cm}$ is the best treatment with a moisture content of $12.5 \%$, angle of repose of $36.2^{\circ}$, uniformity index of mesh 40 of $91.2 \%$, mesh of $6039,9 \%$, mesh $8038.1 \%$, bulk density $0.428 \mathrm{~kg} / \mathrm{cm} 3$, grain yield $25.3 \%$, and orange turmeric color.
\end{abstract}

Keywords: drying temperature, slice thickness, flour turmeric, water conten, angle of repose.

\section{PENDAHULUAN}

Indonesia adalah salah satu negara agraris yang memiliki keanekaragaman tanaman herbal di dunia, dimana lebih dari 50 variestas tanaman tersebut tumbuh subur di Indonesia (Peter dan Hall, 2001) dan salah satu jenis tanaman herbal yang banyak dijumpai yaitu kunyit (Curcuma domestica Val). Kunyit mempunyai banyak manfaat diantaranya sebagai jamu kunyit, pewarna alami, bumbu dapur, selain itu kunyit juga banyak digunakan sebagai zat pewarna, bahan campuran kosmetik, ramuan obat-obatan tradisional dan pelengkap dalam upacara keagamaan
(Anonimus, 1977). Tepung kunyit sangat bermanfaat di berbagai industri antara lain untuk bahan baku industry obat-obatan, jamu, kosmetik, dan pewarna tekstil. Selain hal tersebut, tepung kunyit juga merupakan komuditas ekspor dengan nilai jual yang tinggi. Bahan baku tepung kunyit adalah kunyit yang telah dikeringkan, untuk skala industri kunyit yang dikeringkan harus seragam sehingga dapat diperoleh bubuk kunyit yang berkualitas. Untuk mendapatkan kunyit kering yang seragam dengan kualitas yang baik, biasanya dilakukan proses pengeringan dengan memanfaatkan alat pengering mekanis. Untuk mendapatkan kualitas tepung kunyit kering dengan 
mutu yang memadai, maka perlu diperhatikan beberapa faktor yang mempengaruhi proses pengeringan diantaranya suhu pengeringan dan ketebalan irisan kunyit. penelitian ini dilakukan dengan tujuan untuk mendapatkan perlakuan yang menghasilkan sifat fisik terbaik pada tepung kunyit.

\section{METODE}

\section{Tempat dan Waktu Penelitian}

Penelitian ini dilakukan di Laboratorium Teknik Pascapanen, Fakultas Teknologi Pertanian, Universitas Udayana pada bulan Maret sampai Mei 2019.

\section{Alat dan Bahan Penelitian}

Bahan yang digunakan adalah rimpang kunyit kuning yang diperoleh dari petani di Desa Carangsari, Kecamatan Petang, Kabupaten Badung. Alat yang digunakan adalah stopwatch, pisau, timbangan digital skala 5kg (Model Camry), timbangan analitik (Model Shimadzu, Jepang), oven (Blue-m), cawan, loyang, ayakan tyler, corong, gelas ukur, mesin penepung (Mildish), kamera, dan alat tulis.

\section{Kadar Air}

Pengkuran kadar air menggunakan metode oven (SNI, 2323:2008), yakni dimulai dengan cara mengeringkan cawan kosong terlebih dahulu selama 10 menit (M0) kemudian kunyit ditimbang sebanyak 5 gram lalu dimasukan ke dalam cawan tersebut. Cawan berserta isinya (M1) ditempatkan dalam oven selama 4 jam. Setelah 4 jam, cawan beserta isinya dimasukkan ke dalam desikator. Kemudian timbang cawan beserta isinya tersebut (M2). Kadar air dinyatakan dalam presentase bobot seperti berikut :

Keterangan :

$$
\text { Kadar air }=\frac{M 1-M 2}{M 1-M 0} \times 100 \%
$$

$$
\begin{aligned}
& \mathrm{M}_{1}=\text { Berat awal bahan }+ \text { cawan }(\mathrm{g}) \\
& \mathrm{M}_{2}=\text { Berat akhir bahan }+ \text { cawan }(\mathrm{g}) \\
& \mathrm{M}_{0}=\text { Berat cawan kosong }(\mathrm{g})
\end{aligned}
$$

\section{Sudut Curah}

Sudut curah adalah sudut antara permukaan gundukan terhadap permukaan horizontal. Besarya sudut curah dipengaruhi oleh kadar air, massa jenis, luas permukaan dan koefisien gesekan bahan. Untuk mengetahui sudut curah (angle of repose) dapat dihitung dengan cara mencurahkan 50gram tepung kunyit pada satu titik sehingga tepung kunyit berbentuk curahan yang menyerupai kerucut, sehingga sudut curah dapat dihitung sebagai berikut (Dennis R.H dan R. Paul singh, 1980):

Keterangan : $\mathrm{t}=$ Tinggi tumpukan tepung kunyit

$\mathrm{d}=$ Diameter tepung kunyit

\section{Indeks Keseragaman}

Pengukuran keseragaman butiran tepung kunyit dilakukan dengan pengayakan menggunakan ayakan tyler. Hasil dari pengayakan dikelompokkan berdasarkan kriteria kasar, sedang, dan halus. Tepung yang termasuk katagori kasar adalah jumlah fraksi berat yang bertahan pada mesh 40. Sedangkan fraksi berat yang bertahan pada ayakan berikutnya yaitu mesh 60 termasuk dalam katagori sedang. Jumlah fraksi berat pada ayakan selanjutnya yaitu mesh 80 digolongkan dalam katagori halus.

\section{Rendemen Butiran}

Rendemen butiran menunjukkan persen hasil ukuran butiran yang diharapkan, yaitu perbandingan berat butiran yang diharapkan mesh 80 (katagori halus) dengan berat total butiran. (Priastuti, 2016)

Keterangan :

$$
\text { Rendemen butiran }=\frac{W h}{\text { Wtotal }} \times 100 \% \text {. }
$$

$\mathrm{Wh}=$ Berat butiran tepung kunyit $(\mathrm{g})$

Wtotal $=$ Berat total butiran tepung kunyit $(\mathrm{g})$

\section{Kerapatan Curah}

Pengukuran kerapatan curah tepung kunyit dilakukan dengan cara menimbang gelas ukur $\left(\mathrm{W}_{1}\right)$, kemudian diisi dengan tepung kunyit. Mampatkan tepung dengan cara mengetukan gelas ukur secara berulang. Diamati volume tepung kunyit setiap 10 kali ketukan, lalu ditimbang $\left(\mathrm{W}_{2}\right)$ (Priastuti, 2016).

Untuk mengukur kerapatan curah dapat menggunakan rumus :

$$
\text { Kerapatan curah }\left(\mathrm{kg} / \mathrm{cm}^{3}\right)=\frac{W 2-W 1}{V}
$$

Keterangan :

$\mathrm{W} 1=$ Berat gelas ukur $(\mathrm{kg})$

$\mathrm{W}_{2}=$ Berat gelas ukur + tepung kunyit $(\mathrm{kg})$

$\mathrm{V}=$ Volume gelas ukur $\left(\mathrm{cm}^{3}\right)$

\section{Warna}

Pengukuran warna tepung kunyit bertujuan untuk mengetahui warna produk berupa parameter $\mathrm{L}$, a, dan $\mathrm{b}$ berdasarkan Hunter system. Pengukuran parameter $\mathrm{L}, \mathrm{a}, \mathrm{b}$ dilakukan dengan menggunakan color meter (Minolta CR 10) pada setiap permukaan tepung kunyit untuk masing-masing penelitian kemudian nilainya dirata-rata. Chroma menujukkan intensitas atau kekuatan warna. Menurut Francis (1980) besarnya Chroma dapat dihitung dengan persamaan:

Keterangan :

$$
\text { Chroma }=\left(a^{2}+b^{2}\right)^{1 / 2}
$$

$\mathrm{a}=$ tingkat kemerahan atau kehijauan 
$\mathrm{b}=$ tingkat kekuningan atau kebiruan

\section{Analisis Data}

Analisis data dilakukan dengan mengkompilasi data pengaruh variasi suhu dan ketebalan irisan kunyit terhadap masing-masing parameter. Data yang diperoleh diolah dengan menggunakan program computer Microsoft Excel untuk memperoleh hasil masing-masing parameter, lalu dianalisis menggunakan Analysis of Variance (ANOVA). Apabila terdapat pengaruh yang nyata maka analisis data dilanjutkan menggunakan uji BNT (Beda Nyata Terkecil).

\section{HASIL DAN PEMBAHASAN}

\section{Kadar air}

Tabel 1. Nilai rata-rata kadar air (\% Bb) berdasarkan perlakuan ketebalan irisan kunyit

\section{Perlakuan}

$\mathrm{T} 1(0,5 \mathrm{~cm})$

$\mathrm{T} 2(1,0 \mathrm{~cm})$

$\mathrm{T} 3(1,5 \mathrm{~cm})$

Keterangan : Huruf yang berbeda dibelakang nilai rata-rata menunjukkan nilai berbeda nyata.

Berdasarkan hasil analisis ragam diketahui bahwa perlakuan ketebalan irisan kunyit memberikan pengaruh yang signifikan terhadap parameter kadar air yang dihasilkan. Selanjutnya berdasarkan nilai rata-rata yang dtunjukkan pada Tabel 1 diketahui bahwa kadar air tepung kunyit berkisar antara $11 \%$ $14 \% B b$. dimana nilai kadar air terendah yaitu $11 \% \mathrm{Bb}$ diperoleh pada perlakuan ketebalan irisan kunyit $1 \mathrm{~cm}$ (T2). Sementara kadar air tertinggi diperoleh pada perlakuan ketebalan irisan kunyit $1,5 \mathrm{~cm}$ (T3) yaitu sebesar $14,1 \% B b$. Selanjutnya berdasarkan hasil uji lanjut yang dilakukan, diketahui bahwa perlakuan ketebalan irisan kunyit $1 \mathrm{~cm}$ (T2) memberikan pengaruh yang berbeda nyata dibandingkan perlakuan lainnya. hal ini menunjukkan bahwa semakin tipis irisan kunyit, maka semakin cepat proses pemindahan sejumlah air dari dalam bahan ke udara pengering.

Tabel 2. Nilai rata-rata kadar air berdasarkan perlakuan suhu pengeringan

\section{Perlakuan}

Suhu $50^{\circ} \mathrm{C}$

Suhu $60^{\circ} \mathrm{C}$ Nilai rata-rata $(\% \mathrm{Bb})$

Keterangan : Huruf yang tidak sama dibelakang nilai rata-rata menunjukkan nilai berbeda nyata.

Selain ketebalan irisan, suhu pengeringan juga memberikan pengaruh yang signifikan terhadap parameter kadar air yang dihasilkan. Selanjutnya berdasarkan data yang ditunjukan pada tabel 2 diketahui bahwa kadar air tepung kunyit yang dikeringkan dengan suhu $60^{\circ} \mathrm{C}$ memberikan pengaruh yang berbeda nyata dibandingkan dengan pengeringan pada suhu $50^{\circ} \mathrm{C}$. Nilai rata-rata kadar air tepung kunyit dengan suhu pengeringan $50^{\circ} \mathrm{C}$ adalah $13,3 \% \mathrm{Bb}$, sedangkan nilai rata-rata kadar air tepung kunyit dengan suhu pengeringan $60^{\circ} \mathrm{C}$ adalah $10,5 \% \mathrm{Bb}$. Hal ini dikarenakan semakin tinggi suhu pengeringan menyebabkan energi panas yang di hasilkan makin besar, sehingga makin banyak masa cairan yang ada di permukaan bahan yang diuapkan.

\section{Sudut Curah}

Tabel 3. Nilai rata-rata sudut curah $\left({ }^{\circ}\right)$ pada perlakuan ketebalan irisan kunyit.

\begin{tabular}{cc}
\hline Perlakuan & Nilai rata-rata $\left({ }^{\circ}\right)$ \\
T1 $($ Ketebalan $0,5 \mathrm{~cm})$ & $36,2^{\circ} a$ \\
T2 $($ Ketebalan $1 \mathrm{~cm})$ & $38,0^{\circ} b$ \\
T3 (Ketebalan $1,5 \mathrm{~cm})$ & $41,4^{\circ} c$ \\
\hline
\end{tabular}

Keterangan : Huruf yang berbeda dibelakang nilai rata-rata menunjukkan nilai berbeda nyata.

Berdasarkan hasil analisis ragam menunjukkan bahwa perlakuan suhu pengeringan dan perlakuan ketebalan irisan kunyit memberikan pengaruh yang signifikan terhadap sudut curah yang dihasilkan. Selanjutnya berdasarkan nilai rata-rata yang ditunjukkan pada tabel 3 diketahui bahwa sudut curah berkisar antara $36^{\circ}-41^{\circ}$. Nilai sudut curah terkecil yaitu $36,2^{\circ}$ diperloleh pada perlakuan ketebalan irisan kunyit $0,5 \mathrm{~cm}$ (T1) dan sudut curah terbesar diperoleh perlakuan ketebalan irisan kunyit 1,5 cm (T3). Berdasarkan hasil analisis uji lanjut dilakukan, diketahui bahwa sudut curah terkecil diperoleh pada perlakuan ketebalan irisan kunyit $0,5 \mathrm{~cm}$ (T1) yaitu sebesar $36,2^{\circ}$ memberikan pengaruh yang berbeda nyata dibandingkan perlakuan lainnya.

Tabel 4. Nilai rata-rata sudut curah pada perlakuan suhu pengeringan

\begin{tabular}{lc}
\multicolumn{1}{r}{ Perlakuan } & Nilai rata-rata $\left(^{\circ}\right)$ \\
Suhu $50^{\circ} \mathrm{C}$ & $40,9^{\circ} a$ \\
Suhu $60^{\circ} \mathrm{C}$ & $36,2^{\circ} b$ \\
\hline
\end{tabular}

Keterangan : Huruf yang berbeda dibelakang nilai rata-rata menunjukkan nilai berbeda nyata.

Perlakuan suhu pengeringan memberikan pengaruh yang signifikan terhadap sudut curah tepung kunyit yang dihasilkan. Berdasarkan nilai rata-rata yang ditampilkan dalam Tabel 4 diketahui bahwa sudut curah tepung kunyit dengan suhu pengeringan $60^{\circ} \mathrm{C}$ berbeda nyata dengan suhu pengeringan $50^{\circ} \mathrm{C}$. Dalam penelitian ini sudut curah yang dihasilkan pada masing-masing perlakuan tergolong cukup baik dimana sudut curah yang dihasilkan berkisar antara 
$38^{\circ}-42^{\circ}$, dimana nilai sudut curah bahan berbentuk padatan biasanya berkisar $25^{\circ}-50^{\circ}$. Namun, dalam penelitian ini sudut curah yang dihasilkan pada perlakuaan suhu pengeringan $60^{\circ} \mathrm{C}$. dinilai lebih baik. Sesuai dengan pernyataan Anwar et al (2004) yang menyatakan bahwa sudut curah yang mempunyai nilai kecil menunjukkan indeks aliran tepung semakin baik.

\section{Indeks Keseragaman}

Berdasarkan hasil analisis ragam diketahui, perlakuan suhu pengeringan, perlakuan ketebalan irisan kunyit, dan interaksi antar perlakuan memberikan pengaruh yang signifikan $(\mathrm{P}<0,05) \quad$ terhadap indeks keseragaman tepung kunyit yang dihasilkan. Selanjutnya berdasarkan rata-rata yang ditunjukkan pada Tabel 5 diketahui bahwa rata-rata indeks keseragaman tepung kunyit berkisar antara 20\% $80 \%$. Berdasarkan hasil uji lanjut yang dilakukan, diketahui bahwa indeks keseragaman terbesar diperoleh pada kombinasi perlakuan suhu pengeringan $60^{\circ} \mathrm{C}$ dan ketebalan irisan kunyit $1 \mathrm{~cm}$ (S2T2) memberikan pengaruh yang tidak berbeda nyata dengan kombinasi perlakuan suhu pengeringan $50^{\circ} \mathrm{C}$ dan ketebalan irisan kunyit $1 \mathrm{~cm}(\mathrm{~S} 1 \mathrm{~T} 2)$.

Tabel 5. Nilai rata-rata indeks keseragaman (\%)

\begin{tabular}{lccc} 
Perlakuan & \multicolumn{3}{c|}{ Nilai Rata-rata (\%) } \\
& Mesh 40 & Mesh 60 & Mesh 80 \\
S1T1 & $72,5 \% a$ & $38,6 \% b$ & $36,2 \% b$ \\
S1T2 & $89,9 \% b$ & $34,2 \% a$ & $33,4 \% b$ \\
S1T3 & $83,3^{\%} b$ & $28,3 \% a$ & $24,3 \% a$ \\
S2T1 & $73,8^{\%} a$ & $38,0 \% b$ & $35,8 \% b$ \\
S2T2 & $91,2^{\%} c$ & $39,9 \% b$ & $38,1 \% c$ \\
S2T3 & $84,0^{\circ} b$ & $35,4 \% b$ & $32,3 \% b$ \\
\hline
\end{tabular}

Keterangan : Huruf yang sama dibelakang nilai ratarata menunjukkan nilai tidak berbeda nyata $(\mathrm{P}<0,05)$

Besarnya fraksi halus tepung kunyit yang diperoleh pada perlakuan suhu pengeringan $60^{\circ} \mathrm{C}$ dan ketebalan irisan kunyit $1 \mathrm{~cm}(\mathrm{~S} 2 \mathrm{~T} 2)$ menunjukkan bahwa suhu pengeringan dan ketebalan sangat mempengaruhi jumlah tepung kunyit yang dihasilkan dimana penggunaan suhu pengeringan yang tinggi memiliki kemampuan untuk menguapkan air lebih banyak dan semakin tebalnya irisan kunyit yang digunakan akan mempengaruhi banyaknya jumlah tepung kunyit yang dihasilkan.

\section{Kerapatan Curah}

Berdasarkan hasil analisis ragam diketahui bahwa, perlakuan suhu pengeringan, perlakuan ketebalan irisan kunyit dan interaksi antar perlakuan memberikan pengaruh yang signifikan $(\mathrm{P}<0,05)$ terhadap kerapatan curah yang dihasilkan.
Selanjutnya berdasarkan rata-rata yang ditunjukkan pada tabel 6 diketahui bahwa kerapatan curah tepung kunyit berkisar antara $0.318 \mathrm{~kg} / \mathrm{m}^{3}-0.484 \mathrm{~kg} / \mathrm{m}^{3}$. Nilai kerapatan curah tertinggi yaitu $0.484 \mathrm{~kg} / \mathrm{m}^{3}$ diperoleh pada suhu pengeringan $60^{\circ} \mathrm{C}$ dan ketebalan irisan kunyit $1 \mathrm{~cm}$ (S2T2) sedangkan nilai kerapatan curah terendah yaitu $0.318 \mathrm{~kg} / \mathrm{m}^{3}$ diperoleh pada perlakuan suhu pengeringan $50^{\circ} \mathrm{C}$ dan ketebalan 0,5 $\mathrm{cm}(\mathrm{S} 1 \mathrm{~T} 1)$.

Tabel 6. Nilai Rata-rata Kerapatan Curah Tepung Kunyit $\left(\mathrm{kg} / \mathrm{m}^{3}\right)$

\begin{tabular}{lc}
\multicolumn{1}{c}{ Perlakuan } & $\begin{array}{c}\text { Nilai Rata-rata } \\
\left(\mathbf{k g} / \mathbf{m}^{3}\right)\end{array}$ \\
\hline $\mathrm{S} 1 \mathrm{~T} 1\left(50^{\circ} \mathrm{C}\right.$ dan $\left.0,5 \mathrm{~cm}\right)$ & $0.318 \mathrm{~kg} / \mathrm{m}^{3} a$ \\
$\mathrm{~S} 1 \mathrm{~T} 2\left(50^{\circ} \mathrm{C}\right.$ dan $\left.1 \mathrm{~cm}\right)$ & $0.423 \mathrm{~kg} / \mathrm{m}^{3} d$ \\
S1T3 $\left(50^{\circ} \mathrm{C}\right.$ dan $\left.1,5 \mathrm{~cm}\right)$ & $0.354 \mathrm{~kg} / \mathrm{m}^{3} b$ \\
S2T1 $\left(60^{\circ} \mathrm{C}\right.$ dan $\left.0,5 \mathrm{~cm}\right)$ & $0.451 \mathrm{~kg} / \mathrm{m}^{3} e$ \\
S2T2 $\left(60^{\circ} \mathrm{C}\right.$ dan $\left.1 \mathrm{~cm}\right)$ & $0.484 \mathrm{~kg} / \mathrm{m}^{3} f$ \\
S2T3 $\left(60^{\circ} \mathrm{C}\right.$ dan $\left.1,5 \mathrm{~cm}\right)$ & $0.384 \mathrm{~kg} / \mathrm{m}^{3} c$ \\
\hline
\end{tabular}

Keterangan : Huruf yang sama dibelakang nilai ratarata menunjukkan nilai tidak berbeda nyata $(\mathrm{P}<0,05)$

\section{Rendemen Butiran}

Tabel 7. Nilai rata-rata rendemen butiran tepung kunyit (\%)

\begin{tabular}{lc}
\multicolumn{1}{c}{ Perlakuan } & $\begin{array}{c}\text { Nilai Rata-rata } \\
(\%)\end{array}$ \\
\hline S1T1 $\left(50^{\circ} \mathrm{C}\right.$ dan $\left.0,5 \mathrm{~cm}\right)$ & $24,1 \% b$ \\
S1T2 $\left(50^{\circ} \mathrm{C}\right.$ dan $\left.1 \mathrm{~cm}\right)$ & $22,2 \% b$ \\
S1T3 $\left(50^{\circ} \mathrm{C}\right.$ dan $\left.1,5 \mathrm{~cm}\right)$ & $16,2 \% a$ \\
S2T1 $\left(60^{\circ} \mathrm{C}\right.$ dan $\left.0,5 \mathrm{~cm}\right)$ & $23,8 \% b$ \\
$\mathrm{~S} 2 \mathrm{~T} 2\left(60^{\circ} \mathrm{C}\right.$ dan $\left.1 \mathrm{~cm}\right)$ & $25,3 \% c$ \\
$\mathrm{~S} 2 \mathrm{~T} 3\left(60^{\circ} \mathrm{C}\right.$ dan $\left.1,5 \mathrm{~cm}\right)$ & $21,5 \% b$ \\
\hline $\mathrm{K}$ &
\end{tabular}

Keterangan : Huruf yang sama dibelakang nilai ratarata menunjukkan nilai tidak berbeda nyata $(\mathrm{P}<0,05)$

Berdasarkan hasil analisis ragam diketahui bahwa, perlakuan suhu pengeringan, perlakuan ketebalan irisan kunyit dan interaksi antar perlakuan memberikan pengaruh yang signifikan $(\mathrm{P}<0,05)$ terhadap rendemen butiran yang dihasilkan. Selanjutnya berdasarkan rata-rata yang ditunjukkan pada tabel 5 diketahui bahwa rendemen butiran tepung kunyit berkisar antara $16 \%-25 \%$. Nilai rendemen butiran tepung kunyit tertinggi yaitu $25,3 \%$ diperoleh pada perlakuan suhu pengeringan $60^{\circ} \mathrm{C}$ dan ketebalan irisan kunyit $1 \mathrm{~cm}$ (S2T2) sedangkan nilai rendemen butiran terendah yaitu $16,2 \%$ diperoleh pada perlakuan suhu pengeringan $50^{\circ} \mathrm{C}$ dan ketebalan irisan 1,5 cm (S1T3). Berdasarkan hasil uji lanjut yang dilakukan, diketahui bahwa nilai rendemen butiran tertinggi diperoleh pada interaksi perlakuan suhu pengeringan $60^{\circ} \mathrm{C}$ dan ketebalan irisan kunyit 1 
$\mathrm{cm}$ (S2T2) memberikan pengaruh yang berbeda nyata dengan interaksi perlakuan lainnya. Tingginya rendemen butiran yang dihasilkan oleh perlakuan suhu pengeringan $60^{\circ} \mathrm{C}$ dan ketebalan irisan kunyit 1 $\mathrm{cm}$ (S2T2) menunjukkan bahwa suhu pengeringan dan ketebalan sangat mempengaruhi rendemen butiran tepung kunyit yang dihasilkan dimana penggunaan suhu pengeringan $60^{\circ} \mathrm{C}$ memiliki kemampuan untuk menguapkan air lebih besar dibandingkan dengan suhu pengeringan $50^{\circ} \mathrm{C}$.

\section{Warna}

Tabel 8. Nilai rata-rata (L)

\begin{tabular}{lc}
\multicolumn{1}{c}{ Perlakuan } & Nilai rata-rata \\
$\mathrm{S} 1 \mathrm{~T} 1\left(50^{\circ} \mathrm{C}\right.$ dan $\left.0,5 \mathrm{~cm}\right)$ & $46,75 b$ \\
$\mathrm{~S} 1 \mathrm{~T} 2\left(50^{\circ} \mathrm{C}\right.$ dan $\left.1 \mathrm{~cm}\right)$ & $45,1 b$ \\
$\mathrm{~S} 1 \mathrm{~T} 3\left(50^{\circ} \mathrm{C}\right.$ dan $\left.1,5 \mathrm{~cm}\right)$ & $44,0 a$ \\
$\mathrm{~S} 2 \mathrm{~T} 1\left(60^{\circ} \mathrm{C}\right.$ dan $\left.0,5 \mathrm{~cm}\right)$ & $42,0 a$ \\
$\mathrm{~S} 2 \mathrm{~T} 2\left(60^{\circ} \mathrm{C}\right.$ dan $\left.1 \mathrm{~cm}\right)$ & $48,0 c$ \\
$\mathrm{~S} 2 \mathrm{~T} 3\left(60^{\circ} \mathrm{C}\right.$ dan $\left.1,5 \mathrm{~cm}\right)$ & $44,3 a$ \\
\hline
\end{tabular}

Keterangan : Huruf yang sama dibelakang nilai ratarata menunjukkan nilai tidak berbeda nyata $(\mathrm{P}<0,05) 1$.

Berdasarkan hasil analisis ragam menunjukkan bahwa interaksi antar perlakuan ketebalan irisan kunyit dan suhu pengeringan berpengaruh yang signifikan $(\mathrm{P}<0,05)$ terhadap perubahan warna $\mathrm{L}$ tepung kunyit yang dihasilkan. Nilai rata-rata warna L yang lebih tinggi menunjukkan semakin terang warna tepung kunyit yang dihasilkan.

Tabel 9. Nilai rata-rata (a)

\section{Perlakuan}

\section{Nilai rata-rata}

$\begin{array}{ll}\mathrm{S} 1 \mathrm{~T} 1\left(50^{\circ} \mathrm{C} \text { dan } 0,5 \mathrm{~cm}\right) & 55,9 a \\ \mathrm{~S} 1 \mathrm{~T} 2\left(50^{\circ} \mathrm{C} \text { dan } 1 \mathrm{~cm}\right) & 57,3 a \\ \mathrm{~S} 1 \mathrm{~T} 3\left(50^{\circ} \mathrm{C} \text { dan } 1,5 \mathrm{~cm}\right) & 61,2 b \\ \mathrm{~S} 2 \mathrm{~T} 1\left(60^{\circ} \mathrm{C} \text { dan } 0,5 \mathrm{~cm}\right) & 57,5 a \\ \mathrm{~S} 2 \mathrm{~T} 2\left(60^{\circ} \mathrm{C} \text { dan } 1 \mathrm{~cm}\right) & 53,4 a \\ \mathrm{~S} 2 \mathrm{~T} 3\left(60^{\circ} \mathrm{C} \text { dan } 1,5 \mathrm{~cm}\right) & 56,8 a\end{array}$

Keterangan: Huruf yang sama dibelakang nilai ratarata menunjukkan nilai tidak berbeda nyata $(\mathrm{P}<0,05)$

Pada perubahan warna a, hasil ragam menunjukkan bahwa interaksi antar perlakuan ketebalan irisan kunyit dan suhu pengeringan memberikan pengaruh yang signifikan $(\mathrm{P}<0,05)$. Nilai rata-rata warna a yang lebih tinggi menunjukkan semakin merah warna tepung kunyit yang dihasilkan.

Pada perubahan warna $b$, hasil ragam menunjukkan bahwa interaksi antar perlakuan ketebalan irisan kunyit dan suhu pengeringan memberikan pengaruh yang signifikan $(\mathrm{P}<0,05)$. Nilai rata-rata warna $b$ yang lebih tinggi menunjukkan semakin kuning warna tepung kunyit yang dihasilkan. Tepung kunyit belum memiliki nilai SNI untuk hasil pengukuran standar indeks warna, namun warna yang diharapkan dari tepung kunyit yaitu warna kuning-orange (Manoi,2013). Dari penelitian ini tingkat warna yang dihasilkan berbeda, hal tersebut dipengaruhi oleh beberapa faktor yaitu suhu pengeringan yang dilakukan ketika proses pengeringan berbeda.

Tabel 10. Nilai rata-rata (b) Perlakuan Nilai rata-rata

\begin{tabular}{ll}
$\mathrm{S} 1 \mathrm{~T} 1\left(50^{\circ} \mathrm{C}\right.$ dan $\left.0,5 \mathrm{~cm}\right)$ & $53,3 \mathrm{~b}$ \\
$\mathrm{~S} 1 \mathrm{~T} 2\left(50^{\circ} \mathrm{C}\right.$ dan $\left.1 \mathrm{~cm}\right)$ & $52,1 b$ \\
$\mathrm{~S} 1 \mathrm{~T} 3\left(50^{\circ} \mathrm{C}\right.$ dan $\left.1,5 \mathrm{~cm}\right)$ & $49,5 a$ \\
$\mathrm{~S} 2 \mathrm{~T} 1\left(60^{\circ} \mathrm{C}\right.$ dan $\left.0,5 \mathrm{~cm}\right)$ & $47,5 a$ \\
$\mathrm{~S} 2 \mathrm{~T} 2\left(60^{\circ} \mathrm{C}\right.$ dan $\left.1 \mathrm{~cm}\right)$ & $57,8 c$ \\
$\mathrm{~S} 2 \mathrm{~T} 3\left(60^{\circ} \mathrm{C}\right.$ dan $\left.1,5 \mathrm{~cm}\right)$ & $53,0 \mathrm{~b}$ \\
\hline
\end{tabular}

Keterangan : Huruf yang sama dibelakang nilai ratarata menunjukkan nilai tidak berbeda nyata $(\mathrm{P}<0,05)$

\section{KESIMPULAN}

Interaksi perlakuan berpengaruh signifikan terhadap parameter kerapatan curah, indeks keseragaman, rendemen butiran dan warna. Selanjutnya perlakuan suhu pengeringan dan ketebalan irisan memberikan pengaruh yang signifikan terhadap parameter kadar air dan sudut curah.

\section{DAFTAR PUSTAKA}

Aisyah, I. (1997). Pengaruh tepung rimpang kunyit (Curcuma domestica Val) terhadap palatabilitas umpan dan reproduksi mencit putih (Mus musculus). Badan Standar Nasional. 2014. Standar Nasional Indonesia (SNI) Nomor : 7953 : 2014 tentang Kunyit.

Arpah, M. (1993). Pengawasan Mutu Pangan. Penerbit Tarsito, Bandung.

Darwis, S. N., Indo, A. M., \& Hasiyah, S. (1991). Tumbuhan Obat dan Famili Zingiberaceae. Badan Penelitian dan Pengembangan Pertanian. Pusat Penelitian dan Pengembangan Tanaman Industri, Bogor.

Geldart, P., R. A Edwards, J.F.D. Greenhalg, C.A. Morgan 1990. Journal Animal Nutrition, $5^{\text {th }}$ Edition. John Wiley \& Sons inc., New York.

Hasanuddin, J.T.P U. Prosiding Seminar Nasional Perhimpunan Teknik Petanian Indonesia 2015. "Peran Perteta dalam Mendukung Swasembada Pangan Nasional 2017"

Khalil. 1990a. Pengaruh Kandungan Air dan Ukuran Partikel terhadap Sifat Fisik Pakan Lokal: Kerapatan Pemadatan Tumpukan dan Berat Jenis: Buku Media Peternakan. 22 (1): 1 - 11 
Naibaho, B., \& Sinambela, B. D. A. (2000). Pengaruh Suhu Pengeringan Terhadap Kelarutan Kukurmin Dari Tepung Kunyit (Cucurma domestica Val) Pada Berbagai Suhu Air. Universitas HKBP Nommensen, Medan.

Peleg, M. dan E.B. Begley. 1983. Physical Properties of Food. Avi Publishing Company, Inc. Wesport Connection.

Prana, M. S., \& Hawkes, J. G. (1981). Kunyit atau Koneng dan Kerabat-kerabat Dekatnya sebagaiBahan Pangan. Buletin Kebun Raya, Bogor.

Priastuti, R. C., \& Suhandy, D. (2017). Pengaruh Arah Dan Ketebalan Irisan Kunyit Terhadap Sifat Fisik Tepung Kunyit Yang Dihasilkan. Jurnal Teknik Pertanian Lampung (Journal of Agricultural Engineering), 5(2).
SARI, W. (2016). Sifat Fisik Bungkil Kedelai sebagai Pakan Ternak dari Berbagai Ukuran Partikel. Fakultas Peternakan Universitas Hasanuddin. Makasar.

Sudarsono dkk. 1996. Kunyit. repository.usu.ac.id Diakses Tanggal 21 Januari 2019.

Winarto, I. W., \& Lentera, T. (2004). Khasiat \& manfaat kunyit. AgroMedia.Winarno, F. G. 1992. Kimia Pangan dan Gizi. PT Gramedia Pustaka Utama. Jakarta.

Wiratarkusumah, M., Kamarudin, A., \& Atjeng, M. (1992). Sifat Fisik Pangan. Departemen Pendidikan dan Kebudayaan Direktorat Jendral Dikti. Pusat Antar Universitas Pangandan Gizi. Institut Pertanian Bogor, Bogor. 